\title{
EFFICACY OF A READING INTERVENTION FOR FIRST-YEAR UNIVERSITY STUDENTS
}

\author{
Naomi Boakye, University of Pretoria, South Africa
}

The purpose of the study was to determine the efficacy of an integrated cognitive and affective approach to improve students' reading proficiency by improving their affective levels and strategy use. A survey was conducted by means of a questionnaire completed by both control and intervention classes before and after the intervention. The participants were 195 first-year university students in both high risk and low risk groups. The data were analysed using t-tests. The findings from the independent and paired t-tests show that students' affective reading levels and their use of appropriate reading strategies increased significantly. The effect sizes were mainly medium to large, as determined by Cohen's $d$. These findings corroborate other studies that have shown an improvement in students' affective reading levels and their ability to comprehend what they read when the integrated approach is used. The paper argues for an integrated approach to students' reading development in order to achieve optimal improvement in their reading proficiency.

Keywords: reading intervention; integrated approach; cognitive and affective techniques; low risk groups; high risk groups.

\section{INTRODUCTION}

It has been well documented by various researchers that many students face challenges in reading comprehension (e.g. Nel, Dreyer \& Kopper, 2004; Ngwenya, 2010; Pretorius, 2000; Torgeson, 2002). The need for educators to assist students to overcome these challenges and to develop the required reading proficiency is crucial, as reading is a fundamental learning skill that is essential to successful academic performance.

In the pursuit of finding ways to improve students' reading proficiency, various techniques, such as explicit instruction of cognitive and metacognitive strategies, have been used in many classrooms (e.g. Dreyer \& Nel, 2003; Koda, 2004; Pressley, 2006). These studies have emphasised teaching techniques such as identifying main ideas, developing vocabulary, summarising, inferencing, applying background knowledge, and evaluating texts. These cognitive solutions are valid and necessary, but do not indicate the social nature of reading nor the affective influence, which are crucial issues in reading development. Reading researchers argue that, in addition to reading being an individual cognitive process, factors such as sociocultural, socioeconomic, and affect (e.g. motivation, interest, attitudes, selfefficacy) also play an important role in reading development (Alderson, 2000; Alvermann, Phelps \& Ridgeway 2007; Grabe \& Stoller, 2011; Guthrie, 2008). Taylor and Yu (2009) argue that a number of learners at school level have low reading proficiency as a result of their low socioeconomic status. Such students have not had adequate reading resources and have had limited exposure to texts and to people who read, resulting in low affective reading levels. Consequently, a number of students at tertiary level have low affective reading levels and poor reading ability (Boakye, Sommerville \& Debusho, 2014; Pretorius, 2000; Torgeson, 2002). The affective dimension of reading is important in developing reading proficiency, as it contributes to students' willingness to read frequently, and consequently to become involved in their reading (Grabe \& Stoller, 2011). In addition, the reader's motivation 
influences his/her use of well-orchestrated strategies to derive meaning (Anderson, 1999; Guthrie 2008; Guthrie \& Klauda 2014; Guthrie et al., 2004).

Although affective factors are crucial in reading development, most reading interventions focus mainly on cognitive-oriented techniques. In addition, the existing affective-oriented interventions are concentrated at school level. For example, Guthrie and his colleagues used affective and cognitive techniques to improve students' reading comprehension at primary and high school level and have reported their interventions to have been highly successful (e.g. Guthrie \& Klauda, 2014; Guthrie et al., 2004). However, these interventions have not been replicated at tertiary level. Interventions that use an integrated approach of cognitive and affective techniques at tertiary level are therefore required to determine the efficacy of the affective approach in respect of students at tertiary level. Thus, the purpose of this paper is to examine the efficacy of an integrated approach to reading instruction at tertiary level. The engagement framework of Guthrie and Wigfield (2000) was adapted and used in an intervention to improve the reading proficiency of first-year university students. The affective factors that were targeted in the study are discussed and a brief explanation of Guthrie and Wigfield's (2000) framework is provided. Subsequently, the study is presented and the results are discussed to determine the efficacy of the intervention.

\section{AFFECTIVE FACTORS IN READING}

In recent times reading researchers have been arguing for an integrated (cognitive and affective) approach to reading development. Guthrie and Wigfield (2000) point out that people read not only because they can, but because they are motivated to do so. In their discussion of higher-order reading processes, Grabe and Stoller (2011) include affective factors such as motivation, attitude and interest, and argue that these play an important role in the reading process. Other reading researchers have shown a high correspondence between one's affective reading levels and reading proficiency (Guthrie \& Klauda, 2014; Mullis, Martin, Foy \& Drucker, 2012; Tse \& Xiao, 2014).

Grabe and Stoller (2011) point out that, in applying background knowledge and metacognitive strategies, the reader uses affective means to achieve cognitive ends. They explain in their situation model of reader interpretation that higher-level processing requires background knowledge, inferencing, reader goals, reader attitudes, reader motivation, and strategies for text and task difficulty (Grabe \& Stoller, 2011: 28, my emphasis). In other words, during the reading process the reader builds a situation model by combining other knowledge sources, such as knowledge of the world, knowledge of text structure, affective influences, and additional inferences. Affective influences therefore form a crucial part of the reader's interpretation of text. Low motivation could therefore lead to shallow processing at the situation model of reader interpretation. It is therefore essential for all the skills and knowledge required for interpretation to be at appropriate levels and to be assembled and coordinated appropriately to achieve comprehension in reading. Alvermann et al. (2007: 369) maintain that feelings, attitudes, motivations, interests, and other affective responses of the reader are used in interacting with the text. Together with other factors, the affective responses determine the amount of reading a reader does. For instance, the reader's affect influences his/her willingness to read and the ability to use appropriate strategies for comprehension. Furthermore, Guthrie and Wigfield (2000: 403) point out that readers are decision-makers whose affect, as well as their language and cognition, plays a role in their reading practices. Tse and Xiao (2014) found that high reading proficiency was associated with reading attitude, reading motivation, and self-efficacy. Researchers such as Alderson (2000), Anderson (1999), Grabe and Stoller (2011), and Stanovich (2000) have identified 
frequent exposure to texts as contributing to adequate levels of the cognitive and affective skills, knowledge, and abilities that are required for academic reading. The affective factors that were targeted for the intervention were motivation (intrinsic and extrinsic), self-efficacy, interest, and attitude. The cognitive factor was strategy use.

Guthrie and Wigfield (2000: 404) define motivation in reading as 'the individual's personal goals, values, and beliefs with regard to the topics, processes, and outcomes of reading'. Intrinsic motivation is the desire to engage in a task or activity for its own sake, and involves curiosity, involvement, enjoyment, and preference for challenge (Deci \& Ryan, 2000: 56; Dörnyei, 2001: 47; Guthrie \& Knowles, 2001: 160). Extrinsic motivation, on the other hand, is externally propelled (e.g. external rewards and recognition) and involves, among others, the desire to complete a task and outperform others. Whereas both intrinsic and extrinsic motivation predict reading amount and frequency of reading, the former is said to be more beneficial, and highly predicts text comprehension (Lau, 2009; Wang \& Guthrie, 2004). However, Dörnyei (1994: 276) argues that extrinsic motivation can be combined with or lead to intrinsic motivation.

Motivation has consistently been related to students' use of strategies and autonomy. Highly motivated readers are said to be strategic and employ deep conceptual strategies to comprehend (Wigfield, Guthrie, Perencevich, Taboada, Lutz Klauda, McRae \& Barbosa, 2008: 432). Fan (2010) found that the use of collaborative strategies had a positive impact on students' reading comprehension and learning motivation. Various means of motivating students have been advocated, with learner autonomy and student choices being the most significant. In the intervention reported on, intrinsic motivation was targeted through autonomy, relevant texts, learning goal, and extensive reading. Extrinsic motivation was derived by rewarding students for good performance in various ways.

Reading self-efficacy implies that readers believe in their ability to read successfully (Pajares, 2006). Various studies have shown a consistent relationship between students' self-efficacy and their reading achievement scores (Ghonsooly \& Elahi, 2010; Pajares, 2006; Van Kraayenoord \& Schneider, 1999). Ghonsooly and Elahi (2010) examined the reading selfefficacy of Japanese EFL university students and found a positive relationship between participants' self-efficacy in reading and their reading achievement. They attributed this to low anxiety and frequent strategy use among learners with high self-efficacy. Van Kraayenoord and Schneider (1999), in their study among German school learners, found that higher reading achievement corresponded with higher metacognition and self-efficacy. Consequently, strategy instruction has been proposed as a means of increasing self-efficacy (Dörnyei, 1994: 282).

Like intrinsic motivation, personal interest in reading is internal and is the enduring attraction to a topic even before a particular text is read (Hidi \& Anderson, 1992: 216; Schiefele, 1992: 152). Situational interest, on the other hand, is external and triggered by environmental factors. It is defined by Hidi and Anderson (1992: 216) as a 'short-lived emotional state educed within a particular context'. Although a combination of personal interest and situational interest increases reading comprehension, research has shown a positive relationship between personal interest in particular, and reading comprehension (Schiefele, 1992; Squires, 2014). Text-based interest, a form of situational interest, is the interest in reading specific texts and can be created by compiling reading materials from a selection of topics and themes. Hidi and Anderson (1992: 229) and Schiefele (1992: 159) claim that interest created in this way is a particular form of situational interest that could develop into long-lasting, personal interest. 
Attitude towards reading is 'a system of feelings related to reading, which causes the learner to approach or avoid a reading situation' (Guthrie \& Knowles, 2001: 161; McKenna, 2001: 136). Reading researchers (e.g. Guthrie \& Wigfield, 2000; McKenna, 2001: 135) believe that a positive attitude promotes engaged reading. Thames and Reeves-Kazelskis (1992) claim that reading attitude is a major determining factor in the degree of students' willingness to engage in reading activities. Swalander and Taube (2007) showed in their correlational study that reading attitude influenced reading ability.

McKenna (2001: 140) proposes two principal beliefs that affect attitude: the reading activity itself and how one's friends view reading. He extends this distinction to include three principal factors in the acquisition of attitudes towards reading: the direct impact of reading episodes; beliefs about the outcomes of reading; and beliefs about cultural norms concerning reading. His model posits that attitudes are shaped over an extended period through the influence of these three factors. He argues that, if one were to succeed in changing students' negative attitudes towards reading, then one should target the factors that affect those attitudes (McKenna, 2001: 139).

In justifying why reading attitude may not always relate to reading behaviour or predict reading behaviour, Matthewson (2004) provides a tri-component view of attitude. He argues that certain variables affect the relationship between attitude and reading behaviour, and proposes intention to read as the central component that mediates the attitude-reading relationship. Although Yamashita (2004) did not find a relationship between the evaluation component and students' reading, he did find a positive relationship between the affective component, and students' reading amount and reading behaviour. He concludes from his study that "merely thinking that reading is good for oneself does not constitute a sufficiently strong motivation' to read (Yamashita, 2004: 13). The seemingly inconsistent results of attitude research could be due to the fact that attitude, specifically reading attitude, is a complex theoretical construct (Matthewson, 2004; Yamashita, 2004).

In relation to actual classroom techniques, incentive programmes, among others, have been suggested as a means to improve students' attitudes (Mathewson, 2004; McKenna, 2001). These authors argue that incentives contribute to the amount of reading students do. McKenna (2001) suggests peer interaction as a means to develop positive attitudes. Research has shown that peer interaction, in the form of discussion groups about books read, can lead to improved attitudes towards reading. It exposes students to their peers' positive attitudes, and may influence perceptions of negative social norms (McKenna, 2001: 151). McKenna's proposal is echoed by Guthrie and Wigfield (2000) in their argument for the necessity of creating a community of readers in order to cultivate engaged readers.

Fluent reading involves the use of well-orchestrated strategies, and for a reader to be strategic he/she has to be motivated. In other words, the reader has to have a positive attitude, high interest and the willingness to read, which will result in the application of strategies and the enhancement of comprehension abilities. When students are motivated, 'they view themselves as competent readers who are in control of their comprehension processes; they are said to be strategic in their approach to reading' (Alvermann et al., 2007: 29), and consequently, successful readers. Explicit instruction of reading strategies was used in the intervention to improve students' reading proficiency and promote engaged reading.

\section{Engaged reading}

Engaged reading contributes to high reading proficiency. Guthrie and Wigfield (2000: 404) contend that high affective reading levels culminate in reading engagement, which they 
define as 'the motivated use of strategies to gain conceptual knowledge during reading', consciously or unconsciously. The reader achieves this through a state of total absorption and involvement, as explained by Guthrie and Wigfield (2000: 404). They argue that engagement leads to improved reading comprehension ability, which can compensate for inadequacies in reading comprehension due to poor socioeconomic background. Guthrie, Schafer and Huang (2001: 145) found that 'reading engagement overcame socioeconomic status as a correlate of reading achievement'.

Guthrie and Wigfield (2000) affirm that an engaged reader is a motivated reader who applies various cognitive and metacognitive strategies to comprehend texts, and his/her interests span across various topics and last for longer. They suggest that reading instruction should be aimed at developing engaged readers by increasing affective responses, such as motivation, interest, attitude, and self-efficacy. They present a framework of instructional techniques that can be used to teach reading strategies to generate engaged reading. The framework comprises the following: learning goals, real-world involvement, autonomy support, interesting texts, strategy instruction, collaboration, praise and rewards, teacher involvement, and evaluation. In relation to the framework, the intervention provided students with:

- explanations and clear goals for tasks (learning goals);

- relevant, real-life issues (real-world involvement);

- choices and responsibilities (autonomy support);

- interesting and relevant texts (interesting texts);

- explicit strategy instruction, such as summarising and inferencing;

- opportunities to collaborate with peers and engage in group work (collaboration);

- rewards and praise (praise and rewards); and

- personal and academic support by the educator (teacher involvement).

The intervention was then assessed in various ways (e.g. portfolios and quizzes; formative and summative assessment) with frequent positive feedback (evaluation).

In addition to the techniques of the framework, extensive reading was included in the intervention programme to increase motivation and promote engaged reading. Teaching took place in a non-threatening environment where the educator acted as a facilitator and afforded students the freedom to explore and learn. This provided a positive teaching and learning experience.

\section{Enrichment programme}

As the students had to write an examination based on the contents of the standard curriculum, the intervention could not be a complete overhaul of the standard curriculum; instead, it had to be an affective enrichment to the standard curriculum. The standard curriculum consisted of cognitive and metacognitive explanations (e.g. strategy instruction, vocabulary development) using generic texts. There was no affective dimension to it. The enrichment consisted of real-life, goal-oriented learning tasks to increase motivation; relevant and interesting discipline-oriented texts to generate interest; explicit strategy instruction to increase competence; various collaborative tasks and activities; choices in assignment topics and selection of texts for autonomy support; increased teacher support, especially for weak students; frequent, positive feedback to increase self-efficacy; praise and rewards for students who excelled to increase motivation; and frequent, continuous assessments, such as compiling portfolios. In addition, extensive reading was included to provide students with exposure to texts and to improve reading habits. Students in the intervention classes were 
required to read a minimum of 50 pages of non-academic texts (e.g. novels) each week for the first two weeks and 100 pages per week thereafter. They had to document affective and cognitive improvements and challenges during their reading to submit as part of their portfolios. A non-threatening teaching environment was created to enable students to feel free to explore and learn. Whereas the intervention groups had the above enrichment, the control groups followed the standard curricula without any enrichment.

\section{THE STUDY}

The aim of the study was to determine the efficacy of an integrated approach to improve students' affective reading levels and reading proficiency. The question that was posed for the study was: What is the efficacy of a reading intervention programme that uses an affective approach?

\section{Participants}

First-year students registered for the Academic Literacy and Academic Reading modules, who belonged to groups assigned to the researcher, were used for the study. Students who were registered for the Academic Literacy module had been identified to be at high risk of academic failure by taking a standardised test for academic literacy levels (TALL). Those who registered for the Academic Reading module were identified to be at low risk of academic failure. In total, 195 students in four groups participated in the study: 76 high risk (35 control, 41 intervention) and 119 low risk (70 control, 49 intervention).

\section{Instrument}

A five-point Likert scale questionnaire from positive to negative was used to elicit students' affective levels, reading habits, and strategy use before and after the intervention. The questionnaire consisted of 56 questions grouped under the seven affective factors: selfefficacy, attitude, interest, strategy use, intrinsic motivation, extrinsic motivation, and reading habits. Questions on interest elicited students' level of passion and pleasure in reading. Questions on attitude probed students' views on the usefulness of reading, among other aspects. Reading self-efficacy questions sought to bring to light the extent to which students believed in their ability to undertake reading tasks successfully. Intrinsic motivation questions determined students' curiosity, involvement, and engagement in reading, whereas extrinsic motivation questions ascertained the level of external influences on students' willingness to read and engagement in reading. Questions pertaining to reading habits probed the extent to which students read for pleasure. The cognitive category of strategy use had questions that related to the type of strategy that students use for comprehension (see Addendum for questionnaire). The Cronbach's alpha reliability ranged from 0.68 to 0.88 for pre-intervention questionnaires and from 0.67 to 0.90 for post-intervention questionnaires. The reliability index was therefore satisfactory.

\section{Procedure}

The pre-intervention questionnaires were completed during one class period within the first two weeks of the academic year. The post-intervention questionnaires were completed after the intervention, but at different times for the low risk and high risk groups. Since the low risk group followed a seven-week curriculum, the post-intervention questionnaires were completed in the seventh week. The high risk group completed the post-intervention questionnaires in the 14th week, as the curriculum runs for a full semester. Students read and signed informed consent forms before completing the questionnaires. 


\section{Data analysis}

T-tests were conducted on the pre-intervention questionnaires to compare the control and intervention classes. The tests were conducted to ensure that both groups started off with similar affective reading levels.

Thereafter, paired t-tests were used to compare pre- and post-intervention questionnaires to determine the improvement in each group. In addition, independent t-tests were administered to compare the results of the control and intervention groups to determine how the groups had improved in comparison. Furthermore, procedures to determine the effect size were applied in both the paired and independent $t$-tests to determine the effect of improvements.

\section{RESULTS}

The results of the high risk and low risk groups are reported on separately, because the duration of the intervention differed. In addition, as the two groups were registered for different modules and the normal programme had to be followed as well, the intervention was applied slightly differently in each group. The low risk group followed the reading intervention programme more closely since the module itself was a reading improvement module. The high risk group had to follow the intervention as an add-on in class, as the reading section of the curriculum was scheduled for the second semester, while the intervention was undertaken in the first semester. The first semester of the curriculum for the high risk group dealt with gathering information and presenting it graphically. Furthermore, the two groups differed in their affective reading levels, as reported in a previous study (Boakye et al., 2014). The high risk group had relatively lower levels of affective reading. Affective issues were therefore strongly emphasised in the intervention for the high risk group, whereas strategy instruction was more dominant in the low risk group.

Independent t-tests show that the control and intervention classes of each group started off with comparable affective levels. There are no statistically significant differences, as $\mathrm{p}$ values are all above $\mathrm{p}=0.05$. Both the low risk group and the high risk group had low affective reading levels, but the high risk group had comparatively lower levels. Students' reading attitudes, however, seemed to be positive. All four groups reported positive attitudes, with the mean ranging between 1.67 and 1.93 on a scale of 1 positive to 5 negative. The results of the independent t-test are given in Table 1. 
Table 1: Results of independent t-test

\begin{tabular}{|c|c|c|c|c|c|c|c|c|}
\hline \multirow[t]{2}{*}{ Category } & \multicolumn{4}{|c|}{ High risk $(n=76)$} & \multicolumn{4}{|c|}{ Low risk $(n=119)$} \\
\hline & Mean & SD & $\mathbf{T}$ & p-value & Mean & SD & $\mathbf{t}$ & p-value \\
\hline $\begin{array}{l}\text { Interest in reading } \\
\text { Intervention } \\
\text { Control }\end{array}$ & $\begin{array}{l}1.87 \\
1.92\end{array}$ & $\begin{array}{l}0.66 \\
0.81\end{array}$ & -0.25 & 0.80 & $\begin{array}{l}2.04 \\
2.12\end{array}$ & $\begin{array}{l}0.79 \\
0.90\end{array}$ & 0.49 & 0.62 \\
\hline $\begin{array}{l}\text { Attitude } \\
\text { Intervention } \\
\text { Control }\end{array}$ & $\begin{array}{l}1.67 \\
1.70\end{array}$ & $\begin{array}{l}0.48 \\
0.63\end{array}$ & -0.26 & 0.79 & $\begin{array}{l}1.93 \\
1.92\end{array}$ & $\begin{array}{l}0.74 \\
0.74\end{array}$ & -0.07 & 0.94 \\
\hline $\begin{array}{l}\text { Self-efficacy } \\
\text { Intervention } \\
\text { Control }\end{array}$ & $\begin{array}{l}2.24 \\
2.32\end{array}$ & $\begin{array}{l}0.79 \\
0.75\end{array}$ & -0.43 & 0.66 & $\begin{array}{l}1.95 \\
2.02\end{array}$ & $\begin{array}{l}0.42 \\
0.72\end{array}$ & 0.49 & 0.48 \\
\hline $\begin{array}{l}\text { Strategy use } \\
\text { Intervention } \\
\text { Control } \\
\end{array}$ & $\begin{array}{l}2.26 \\
2.33 \\
\end{array}$ & $\begin{array}{l}0.69 \\
0.67\end{array}$ & -0.49 & 0.62 & $\begin{array}{l}2.52 \\
2.59\end{array}$ & $\begin{array}{l}0.51 \\
0.57\end{array}$ & 0.63 & 0.53 \\
\hline $\begin{array}{l}\text { Intrinsic } \\
\text { motivation } \\
\text { Intervention } \\
\text { Control }\end{array}$ & $\begin{array}{l}2.25 \\
2.34\end{array}$ & $\begin{array}{l}0.58 \\
0.60\end{array}$ & -0.66 & 0.51 & $\begin{array}{l}2.24 \\
2.36\end{array}$ & $\begin{array}{l}0.65 \\
0.67\end{array}$ & 0.95 & 0.34 \\
\hline $\begin{array}{l}\text { Extrinsic } \\
\text { motivation } \\
\text { Intervention } \\
\text { Control }\end{array}$ & $\begin{array}{l}2.51 \\
2.18\end{array}$ & $\begin{array}{l}0.86 \\
0.77\end{array}$ & 1.75 & 0.08 & $\begin{array}{l}2.72 \\
2.63\end{array}$ & $\begin{array}{l}0.97 \\
0.68\end{array}$ & -0.58 & 0.56 \\
\hline $\begin{array}{l}\text { Reading habits } \\
\text { Intervention } \\
\text { Control } \\
\end{array}$ & $\begin{array}{l}2.43 \\
2.71 \\
\end{array}$ & $\begin{array}{l}0.69 \\
0.65 \\
\end{array}$ & -1.84 & 0.06 & $\begin{array}{l}2.67 \\
2.58\end{array}$ & $\begin{array}{l}0.71 \\
0.70\end{array}$ & -0.62 & 0.53 \\
\hline
\end{tabular}

Legend: DF = (74) for each analysis in high risk group; DF = (117) for each analysis in low risk group, except for self-efficacy $\mathrm{DF}=(113.5)$ and extrinsic motivation $\mathrm{DF}=(79.7)$

Given that the results of the independent t-tests are similar for control and intervention classes, the results of the t-tests comparing the pre- and post-intervention responses are given first in descriptive statistics, and then in inferential statistics.

\section{Descriptive statistics}

The mean scores of the post-intervention questionnaires show differences between the preand post-intervention results in the intervention classes. The intervention classes had more positive responses than the control classes. The scale of the questionnaire ranged from positive 1 to negative 5 ; therefore, the lower the mean figure, the relatively better the response. The mean scores for pre- and post-intervention responses in the control and intervention classes of high risk and low risk groups are given in Table 2. 
Table 2: Pre-and post-intervention means for the groups

\begin{tabular}{|c|c|c|c|c|c|c|c|c|}
\hline \multirow[t]{3}{*}{ Category } & \multicolumn{4}{|c|}{ High risk $(n=76)$} & \multicolumn{4}{|c|}{ Low risk $(n=119)$} \\
\hline & \multicolumn{4}{|c|}{ Pre-intervention Post-intervention } & \multicolumn{4}{|c|}{ Pre-intervention Post-intervention } \\
\hline & Mean & SD & Mean & SD & Mean & SD & Mean & SD \\
\hline \\
\hline Intervention & 1.87 & 0.66 & 1.57 & 0.53 & 2.04 & 0.79 & 1.64 & 0.42 \\
\hline Control & 1.92 & 0.81 & 1.93 & 0.76 & 2.12 & 0.90 & 2.08 & 0.87 \\
\hline \multicolumn{9}{|l|}{ Attitude } \\
\hline Intervention & 1.67 & 0.48 & 1.53 & 0.57 & 1.93 & 0.74 & 1.67 & 0.47 \\
\hline Control & 1.70 & 0.63 & 1.72 & 0.72 & 1.92 & 0.74 & 1.85 & 0.71 \\
\hline \multicolumn{9}{|c|}{\begin{tabular}{l|l} 
Self-efficacy &
\end{tabular}} \\
\hline Intervention & 2.24 & 0.79 & 1.88 & 0.48 & 1.95 & 0.42 & 1.72 & 0.42 \\
\hline Control & 2.32 & 0.75 & 2.37 & 0.79 & 2.02 & 0.72 & 1.80 & 0.70 \\
\hline \multicolumn{9}{|l|}{ Strategy use } \\
\hline Intervention & 2.26 & 0.69 & 1.89 & 0.43 & 2.52 & 0.51 & 2.25 & 0.42 \\
\hline Control & 2.33 & 0.67 & 2.20 & 0.56 & 2.59 & 0.57 & 2.55 & 0.62 \\
\hline \multicolumn{9}{|l|}{ Intrinsic } \\
\hline $\begin{array}{l}\text { motivation } \\
\text { Intervention }\end{array}$ & 2.25 & 0.58 & 1.72 & 0.41 & 2.24 & 0.65 & 1.98 & 0.47 \\
\hline Control & 2.34 & 0.60 & 2.27 & 0.53 & 2.36 & 0.67 & 2.44 & 0.77 \\
\hline \multicolumn{9}{|l|}{ Extrinsic } \\
\hline motivation & & & & & & & & \\
\hline Intervention & 2.51 & 0.86 & 2.01 & 0.61 & 2.72 & 0.97 & 2.50 & 1.10 \\
\hline Control & 2.18 & 0.77 & 2.15 & 0.78 & 2.63 & 0.68 & 2.75 & 0.96 \\
\hline \multicolumn{9}{|l|}{$\begin{array}{l}\text { Reading } \\
\text { habits }\end{array}$} \\
\hline Intervention & 2.43 & 0.69 & 1.82 & 0.46 & 2.67 & 0.71 & 2.22 & 0.51 \\
\hline Control & 2.71 & 0.65 & 2.61 & 0.60 & 2.58 & 0.70 & 2.60 & 0.62 \\
\hline
\end{tabular}

Mean scores for post-intervention results indicate that the intervention classes (high risk and low risk) had more positive responses, and therefore better affective levels, strategy use, and reading habits than they had in the pre-intervention questionnaires. The mean scores also show that the control groups generally worsened or merely retained their pre-intervention affective levels.

\section{Inferential statistics}

The statistical results of the paired t-tests to determine differences between pre- and postintervention results for each group show that the intervention classes improved their affective reading levels, strategy use, and reading habits significantly. The independent t-tests show that there were significant differences between the control classes and intervention classes in terms of improvement.

\section{Paired t-test}

Whereas there were marked differences in the pre- and post-intervention responses of the intervention classes, there were no marked differences in the control classes. The high risk intervention group improved significantly in six of the seven categories: interest $(p=0.001)$, self-efficacy $(p=0.000)$, strategy use $(p=0.001)$, intrinsic motivation $(p=0.000)$, extrinsic motivation $(\mathrm{p}=0.001)$, and reading habits $(\mathrm{p}=0.000)$. The low risk intervention group also 
improved in six of the categories: interest $(p=0.000)$, self-efficacy $(p=0.000)$, strategy use $(\mathrm{p}=0.000)$, intrinsic motivation $(\mathrm{p}=0.001)$, and reading habits $(\mathrm{p}=0.000)$. However, whereas the high risk intervention group showed significant difference in extrinsic motivation, the low risk students did not, and whereas the low risk intervention group improved significantly in their reading attitude, the high risk students did not, as shown in Table 3.

Table 3: Results of paired t-test

\begin{tabular}{|c|c|c|c|c|}
\hline \multirow[t]{2}{*}{ Category } & \multicolumn{2}{|c|}{ High risk $(n=76)$} & \multicolumn{2}{|c|}{ Low risk $(n=119)$} \\
\hline & $\mathbf{t}$ & p-value & $\mathbf{t}$ & p-value \\
\hline $\begin{array}{l}\text { Interest } \\
\text { Intervention } \\
\text { Control } \\
\end{array}$ & $\begin{array}{r}3.35 \\
-0.12 \\
\end{array}$ & $\begin{array}{l}0.001 * * \\
0.907\end{array}$ & $\begin{array}{l}4.32 \\
0.44 \\
\end{array}$ & $\begin{array}{l}0.000 * * \\
0.658\end{array}$ \\
\hline $\begin{array}{l}\text { Attitude } \\
\text { Intervention } \\
\text { Control }\end{array}$ & $\begin{array}{r}1.45 \\
-0.21\end{array}$ & $\begin{array}{l}0.153 \\
0.834\end{array}$ & $\begin{array}{l}2.91 \\
0.73\end{array}$ & $\begin{array}{l}0.005 * * \\
0.465\end{array}$ \\
\hline $\begin{array}{l}\text { Self-efficacy } \\
\text { Intervention } \\
\text { Control } \\
\end{array}$ & $\begin{array}{l}3.95 \\
-0.4 \\
\end{array}$ & $\begin{array}{l}0.000 * * \\
0.690\end{array}$ & $\begin{array}{l}4.1 \\
2.22 \\
\end{array}$ & $\begin{array}{l}0.000 * * \\
0.029 *\end{array}$ \\
\hline $\begin{array}{l}\text { Strategy use } \\
\text { Intervention } \\
\text { Control } \\
\end{array}$ & $\begin{array}{l}3.56 \\
1.61 \\
\end{array}$ & $\begin{array}{l}0.001 * * \\
0.117\end{array}$ & $\begin{array}{l}3.76 \\
0.48 \\
\end{array}$ & $\begin{array}{l}0.000 * * \\
0.635 \\
\end{array}$ \\
\hline $\begin{array}{l}\text { Intrinsic } \\
\text { motivation } \\
\text { Intervention } \\
\text { Control }\end{array}$ & $\begin{array}{l}5.55 \\
0.9\end{array}$ & $\begin{array}{l}0.000 * * \\
0.373\end{array}$ & $\begin{array}{r}3.45 \\
-0.86\end{array}$ & $\begin{array}{l}0.001 \text { ** } \\
0.391\end{array}$ \\
\hline $\begin{array}{l}\text { Extrinsic } \\
\text { motivation } \\
\text { Intervention } \\
\text { Control } \\
\end{array}$ & $\begin{array}{l}3.37 \\
0.33 \\
\end{array}$ & $\begin{array}{l}0.001 \text { ** } \\
0.740\end{array}$ & $\begin{array}{c}1.6 \\
-1.28 \\
\end{array}$ & $\begin{array}{l}0.117 \\
0.203 \\
\end{array}$ \\
\hline $\begin{array}{l}\text { Reading habits } \\
\text { Intervention } \\
\text { Control }\end{array}$ & $\begin{array}{l}5.11 \\
0.1\end{array}$ & $\begin{array}{l}0.000 * * \\
0.365\end{array}$ & $\begin{array}{r}5.36 \\
-0.24\end{array}$ & $\begin{array}{l}0.000 * * \\
0.809\end{array}$ \\
\hline
\end{tabular}

Legend: $\mathrm{t}(\mathrm{t}$-statistic); $\mathrm{p}$ ( $\mathrm{p}$-value) *p $<.05 ; * * \mathrm{p}<.01$

\section{Independent t-test}

The independent t-tests show statistically significant differences between the control and the intervention classes of both high risk and low risk students. For the high risk group, there were statistically significant differences between control and intervention classes in five of the seven categories: interest $(\mathrm{t}(74)=2.36, \mathrm{p}=0.021)$, self-efficacy $(\mathrm{t}(74)=2.82, \mathrm{p}=0.006)$, intrinsic motivation $(\mathrm{t}(74)=3.57, \mathrm{p}=0.000)$, extrinsic motivation $(\mathrm{t}(74)=2.63, \mathrm{p}=0.010)$, and reading habits $(\mathrm{t}(74)=3.09, \mathrm{p}=0.002)$. The difference in the category of strategy use was not significant at $5 \%(\mathrm{p}=0.092)$. Also, responses on reading attitude were not statistically significant. On the whole, the results show that, whereas the affective levels of the intervention class in the high risk group improved, those of the control classes decreased, or even sometimes worsened into negative figures, as shown by the mean figures in Table 4. 
Table 4: Results of independent t-test

\begin{tabular}{|c|c|c|c|c|c|c|c|c|}
\hline \multirow[t]{3}{*}{ Category } & \multicolumn{4}{|c|}{ High risk $(n=76)$} & \multicolumn{4}{|c|}{ Low risk $(n=119)$} \\
\hline & & Impr & ement & & & ImI & vemen & \\
\hline & Mean & SD & $\mathbf{t}$ & p-value & Mean & SD & $\mathbf{t}$ & p-value \\
\hline $\begin{array}{l}\text { Interest } \\
\text { Intervention } \\
\text { Control }\end{array}$ & $\begin{array}{r}0.302 \\
-0.011\end{array}$ & $\begin{array}{l}0.57 \\
0.57\end{array}$ & 2.36 & $0.021 *$ & $\begin{array}{l}0.39 \\
0.04 *\end{array}$ & $\begin{array}{l}0.64 \\
0.75\end{array}$ & -2.69 & $0.008 * *$ \\
\hline $\begin{array}{l}\text { Attitude } \\
\text { Intervention } \\
\text { Control }\end{array}$ & $\begin{array}{r}0.138 \\
-0.019\end{array}$ & $\begin{array}{l}0.60 \\
0.53\end{array}$ & 1.19 & 0.239 & $\begin{array}{l}0.26 \\
0.06\end{array}$ & $\begin{array}{l}0.63 \\
0.78\end{array}$ & -1.42 & 0.157 \\
\hline $\begin{array}{l}\text { Self-efficacy } \\
\text { Intervention } \\
\text { Control }\end{array}$ & $\begin{array}{r}0.363 \\
-0.045\end{array}$ & $\begin{array}{l}0.58 \\
0.67\end{array}$ & 2.28 & $0.006 * *$ & $\begin{array}{l}0.23 \\
0.22\end{array}$ & $\begin{array}{l}0.37 \\
0.84\end{array}$ & 0.02 & 0.983 \\
\hline $\begin{array}{l}\text { Strategy use } \\
\text { Intervention } \\
\text { Control }\end{array}$ & $\begin{array}{l}0.365 \\
0.134\end{array}$ & $\begin{array}{l}0.65 \\
0.49\end{array}$ & 1.7 & 0.092 & $\begin{array}{l}0.27 \\
0.03\end{array}$ & $\begin{array}{l}0.51 \\
0.68\end{array}$ & -2.07 & $0.041 *$ \\
\hline $\begin{array}{l}\text { Intrinsic } \\
\text { motivation } \\
\text { Intervention } \\
\text { Control }\end{array}$ & 0.531 & 0.61 & 3.57 & $0.000 * *$ & 0.26 & 0.54 & -2.68 & $0.008 * *$ \\
\hline $\begin{array}{l}\text { Extrinsic } \\
\text { motivation } \\
\text { Intervention } \\
\text { Control }\end{array}$ & $\begin{array}{l}0.501 \\
0.028\end{array}$ & $\begin{array}{l}0.95 \\
0.50\end{array}$ & 2.75 & $0.007 * *$ & $\begin{array}{r}0.22 \\
-0.12\end{array}$ & $\begin{array}{l}0.97 \\
0.80\end{array}$ & -2.11 & $0.036^{*}$ \\
\hline $\begin{array}{l}\text { Reading } \\
\text { habits } \\
\text { Intervention } \\
\text { Control }\end{array}$ & $\begin{array}{l}0.6010 \\
0.0100\end{array}$ & $\begin{array}{l}0.75 \\
0.64 \\
\end{array}$ & 3.09 & $0.002 * *$ & $\begin{array}{r}0.44 \\
-0.01 \\
\end{array}$ & $\begin{array}{l}0.58 \\
0.52 \\
\end{array}$ & -4.49 & $0.000 * *$ \\
\hline
\end{tabular}

Legend: DF = (74) for each analysis in high risk group except for extrinsic motivation; DF = (62.8); DF = (117) for each analysis in the low risk group; $\mathrm{t}(\mathrm{t}$-values); $\mathrm{p}$ ( $\mathrm{p}$-values); $* \mathrm{p}=\mathrm{p}<.05 ; * * \mathrm{p}=\mathrm{p}<.01$

The responses of the low risk group also show statistically significant differences between the intervention and control classes in five of the seven categories: interest $(\mathrm{t}(117)=-2.69$, $\mathrm{p}=0.008)$, intrinsic motivation $(\mathrm{t}(117)=-2.68, \mathrm{p}=0.008)$, extrinsic motivation $(\mathrm{t}(117)=-2.11, \mathrm{p}=0.036)$, strategy use $(\mathrm{t}(117)=-2.07, \mathrm{p}=0.041)$ and reading habits $(\mathrm{t}(117)=-4.49, \mathrm{p}=0.000)$. There were no statistically significant differences between the improvement of the control and intervention classes of the low risk group with regard to attitude and self-efficacy. However, the mean scores for the two categories show differences in improvement in the intervention class. It is interesting that, in the high risk group, attitude is the only category in which there was no significant difference between the control and intervention classes, and that the same is the case in the low risk group, as shown in Table 4. According to the mean scores given in Table 4, students responded positively to questions on reading attitude in the pre-intervention questionnaire, but this positive attitude did not increase in the control class. In general, students in the intervention class improved significantly in affective level compared to the control class. The improvement differences between the control and intervention classes of the low risk and high risk groups are presented in Figures 1 and 2. 


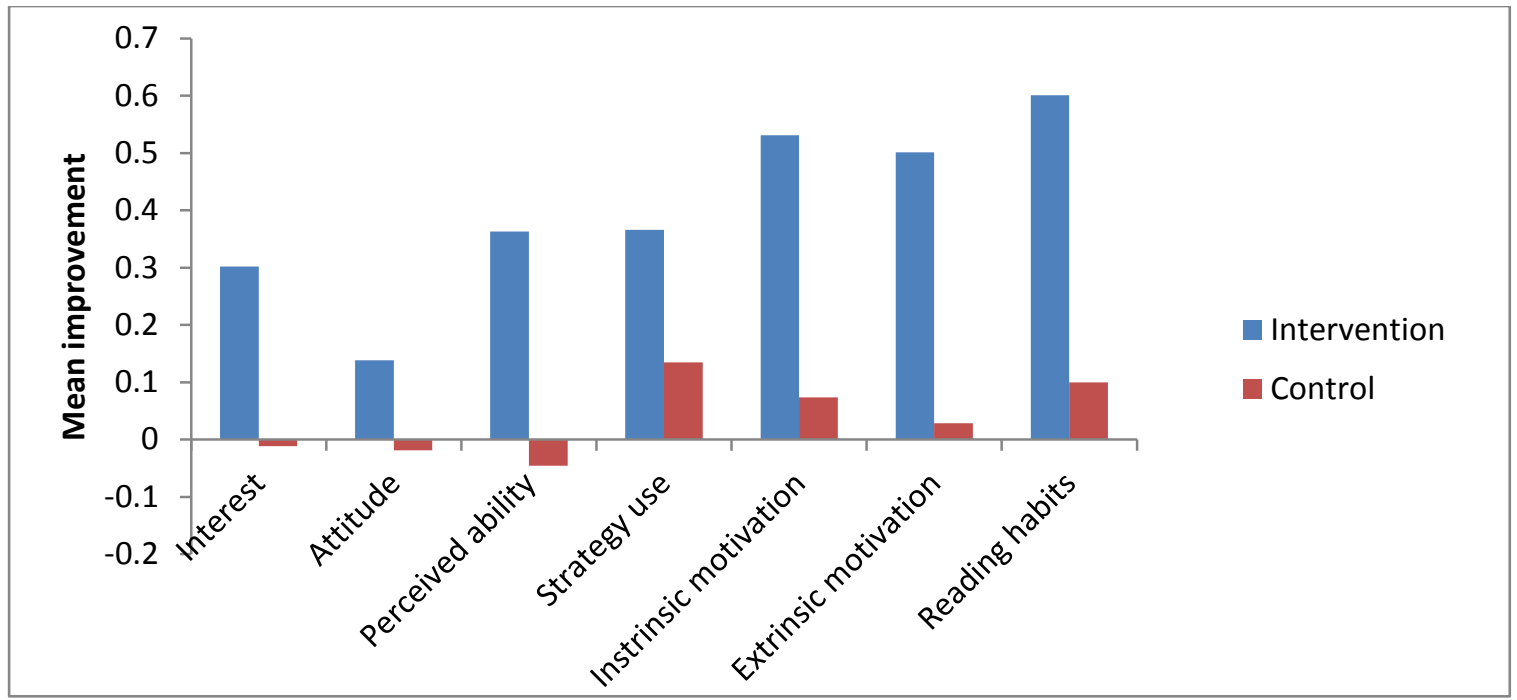

Figure 1: Independent t-test (improvement) scores for intervention and control classes in the high risk group

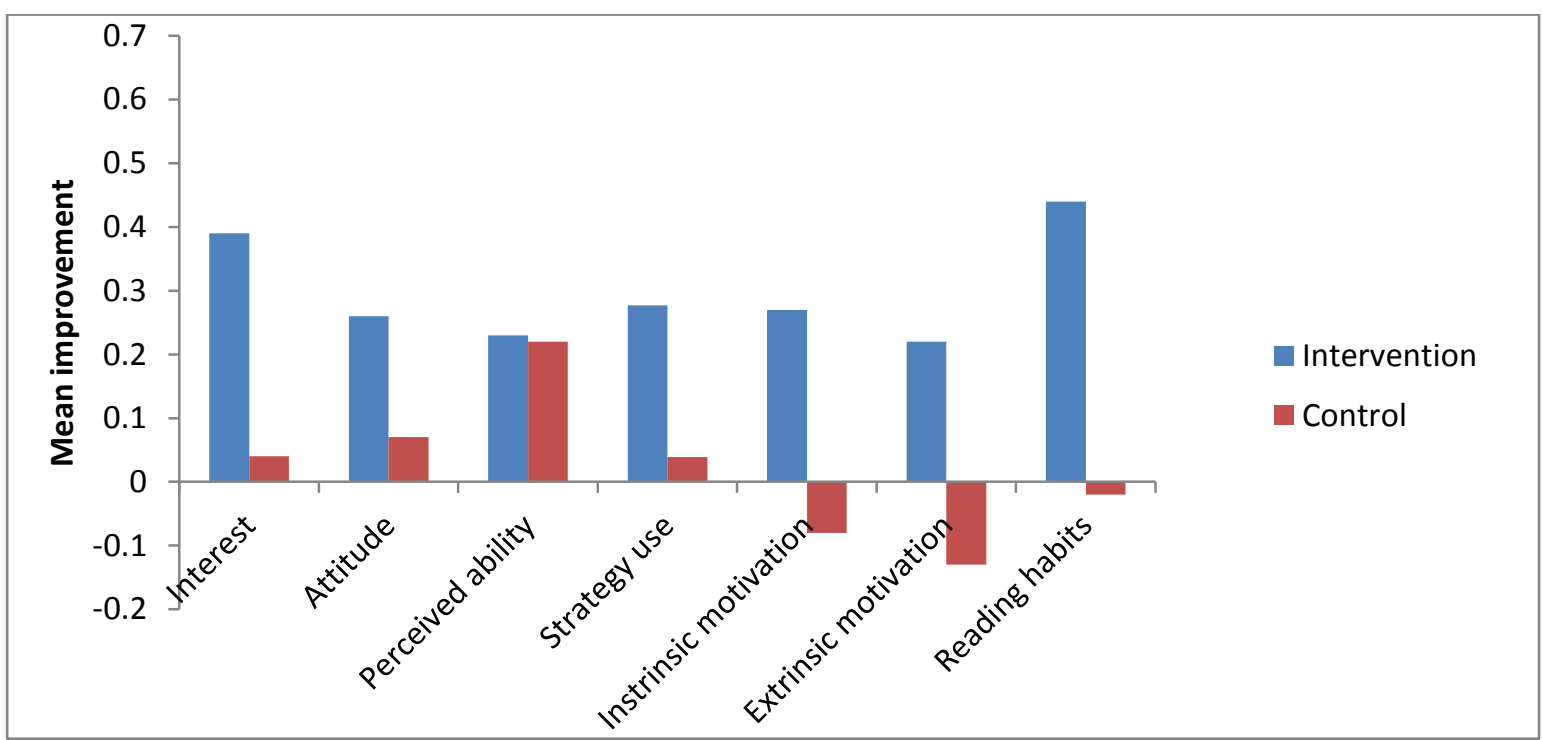

Figure 2: Independent t-test (improvement) scores for intervention and control classes in the low risk group

Although the control classes improved in some categories, the improvements in the intervention classes were statistically significant.

In general, the control classes did not show better affective levels and strategy use than the intervention classes. Where there was no statistically significant difference, the mean figures show that the intervention class improved. The intervention class for both high risk and low risk groups developed a significantly higher interest $(\mathrm{p}=0.021)$, higher levels of self-efficacy $(\mathrm{p}=0.006)$, higher intrinsic and extrinsic motivation $(\mathrm{p}=0.000 ; \mathrm{p}=0.007)$, and better reading habits $(\mathrm{p}=0.002)$.

The decreased affective levels of the control classes, shown in negative figures for the mean, indicate that the affective levels of this cohort of first-year students may have dropped during the first semester. In contrast, the affective teaching approach that was used in the intervention classes increased students' affective levels. The differences between the control 
classes and intervention classes, when all other factors had been controlled, indicate that the approach benefited students in respect of affective levels, reading habits and strategy use.

Given that significant improvement was shown in five of the seven categories in the intervention class of the low risk group, and six out of seven for the high risk group, the affective teaching approach was effective in improving students' affective levels in reading.

\section{Differential performance (effect sizes)}

To determine the extent of the improvement, an effect size procedure using Cohen's $d$ was applied to each of the seven categories. Glass, McGaw and Smith (1981:104) argue that, in education, if academic achievement can be raised by an effect size of even as little as 0.1 , it could be perceived as a significant improvement. Table 5 shows effect sizes in the significant differences within each group, while Table 6 shows effect size differences between the intervention and control classes.

Table 5: Effect sizes of paired t-tests within groups

\begin{tabular}{|c|c|c|c|c|}
\hline \multirow[t]{2}{*}{ Category } & \multicolumn{2}{|c|}{ High risk } & \multicolumn{2}{|c|}{ Low risk } \\
\hline & Cohen's d & Effect size & Cohen's d & Effect size \\
\hline $\begin{array}{l}\text { Interest } \\
\text { Intervention }\end{array}$ & 0.499 & M & 0.622 & M-L \\
\hline $\begin{array}{l}\text { Attitude } \\
\text { Intervention }\end{array}$ & & & 0.419 & S-M \\
\hline $\begin{array}{l}\text { Self-efficacy } \\
\text { Intervention } \\
\text { Control }\end{array}$ & 0.552 & M & $\begin{array}{l}0.525 \\
0.315 \\
\end{array}$ & $\begin{array}{l}\mathrm{M} \\
\mathrm{S}-\mathrm{M}\end{array}$ \\
\hline $\begin{array}{l}\text { Strategy use } \\
\text { Intervention }\end{array}$ & 0.632 & M-L & 0.585 & $\mathrm{M}$ \\
\hline $\begin{array}{l}\text { Intrinsic } \\
\text { motivation } \\
\text { Intervention }\end{array}$ & 1.041 & $\mathrm{~L}$ & 0.465 & $\mathrm{M}$ \\
\hline $\begin{array}{l}\text { Extrinsic } \\
\text { motivation } \\
\text { Intervention }\end{array}$ & 0.670 & M-L & & \\
\hline $\begin{array}{l}\text { Reading habits } \\
\text { Intervention }\end{array}$ & 1.013 & $\mathrm{~L}$ & 0.720 & M-L \\
\hline
\end{tabular}

Legend: $M$ = medium effect; $L=$ large effect; $S=$ small effect 
Table 6: Effect sizes of independent t-test (improvement across groups)

\begin{tabular}{|l|lc|lc|}
\hline \multirow{2}{*}{ Categories } & \multicolumn{2}{|c|}{ High risk } & \multicolumn{2}{c|}{ Low risk } \\
\cline { 2 - 5 } & Cohen's d & Effect size & Cohen's d & Effect size \\
\hline $\begin{array}{l}\text { Interest } \\
\text { Intervention }\end{array}$ & 0.550 & M & -0.505 & M \\
\hline $\begin{array}{l}\text { Attitude } \\
\text { Intervention }\end{array}$ & & & \\
\hline $\begin{array}{l}\text { Self-efficacy } \\
\text { Intervention }\end{array}$ & 0.657 & M & & \\
\hline $\begin{array}{l}\text { Strategy use } \\
\text { Intervention }\end{array}$ & & -0.388 & S-M \\
\hline $\begin{array}{l}\text { Intrinsic } \\
\text { motivation } \\
\text { Intervention }\end{array}$ & 0.832 & L & -0.503 & M \\
\hline $\begin{array}{l}\text { Extrinsic } \\
\text { motivation } \\
\text { Intervention }\end{array}$ & 0.641 & M & -396 & S-M \\
\hline $\begin{array}{l}\text { Reading habits } \\
\text { Intervention }\end{array}$ & 0.720 & M-L & -843 & L \\
\hline
\end{tabular}

Legend: $\mathrm{M}=$ medium effect; $\mathrm{L}=$ large effect; $\mathrm{S}=$ small effect

On the whole, there were mainly medium and large effects for intervention classes. However, whereas the low risk group had small to medium effects in two categories, the paired t-tests show that the high risk group had medium to large effects in all the statistically significant categories. Also, effect sizes for the independent t-tests show that the high risk intervention group had medium and large effects, whereas the low risk intervention group had small to medium effects in some categories. As in the paired t-tests, the results of the independent $\mathrm{t}$ tests show that the high risk intervention group had a larger improvement than the low risk intervention group.

In sum, the effect sizes show that the effect of the intervention was significantly noteworthy. Effect sizes show not only that the affective levels of the intervention classes had improved more than the control classes, but also that the sizes of the improvements were medium and large. Considering that affective levels correspond with reading achievement, it could be concluded that the medium and large effect sizes obtained in affective levels, as shown in Tables 5 and 6, imply that a significant improvement occurred in students' affective reading levels.

\section{DISCUSSION}

In general, students in the intervention classes improved significantly in affective reading levels compared to those in the control classes. The fact that the intervention classes in both high risk and low risk groups showed significant improvement in the category of interest indicates that students in these classes developed a relatively higher interest in reading after the intervention. A high interest in reading means higher motivation to read. According to Deci (1992: 43) 'interest is a powerful motivator' and can lead to enjoyment, involvement, and absorption. These payoffs are also features of engagement. It can therefore be assumed that the deep interest that students developed in reading also increased their motivation to read and that they read with enjoyment, involvement, and consequently, engagement. 
The significant improvement in self-efficacy of the high risk intervention group indicates that students developed positive beliefs in their ability to read texts successfully. Self-efficacy is a strong predictor of reading proficiency and academic success (Grabe \& Stoller, 2011; Guthrie \& Wigfield, 2000:408; Mills, Pajares \& Herron, 2007); therefore, one could conclude that these students improved their reading proficiency as well as their academic performance. Improvement in self-efficacy for the low risk intervention group was not statistically significant. However, mean scores show that the intervention class improved. It should be borne in mind that the low risk group started off with relatively higher self-efficacy than the high risk group. The minimal improvement in self-efficacy of the low risk intervention group could be ascribed to the fact that the initial self-efficacy stemming from their high school achievement had dropped at the start of tertiary studies and was only beginning to improve at the time of administering the post-intervention questionnaire.

The fact that attitude did not show significant differences in either high risk or low risk group calls for further investigation into the attitude factor. However, it should be noted that all four classes started off with positive attitudes, as shown in pre-intervention questionnaires. The fact that the improvement was not statistically significant after the intervention could be explained in light of Matthewson's (2004) model, which posits that certain factors mediate the relationship between attitude and behaviour. In addition, Yamashita (2004) found that, in relation to Matthewson's tri-component view of attitude, students improved in the affective, but not in the evaluative, component. It could be that the number of questions on the affective component was inadequate to show statistically significant results. In addition, the intervention period may have been too short to influence students' reading attitude. McKenna's (2001) model posits that it takes much longer for attitude to manifest in behaviour. A similar argument of time constraint could be presented for the non-significant improvement in self-efficacy for the low risk group. Although a significant difference was recorded for strategy use, which should have improved self-efficacy, the improvement in the use of strategies may not yet have been internalised to influence self-efficacy levels due to the short duration of the intervention.

The statistically significant improvement in intrinsic and extrinsic motivation of the intervention classes means that students in these classes became more absorbed, interested, involved, and engaged readers (Deci \& Ryan, 2000; Guthrie \& Wigfield, 2000). They were also motivated by external influences such as marks, praise, and other rewards. According to Deci and Ryan (2000), extrinsic motivation can become internalised and integrated into the self, resulting in intrinsic motivation. From this point of view, it could be assumed that students' extrinsic motivation had been internalised, leading to frequent and engaged reading.

The fact that students significantly improved their strategy use could indicate that they had obtained a higher level of self-efficacy. In addition, the use of appropriate reading strategies could greatly assist students in reading comprehension and critical reading (Grabe, 2008). Comprehension challenges at tertiary level, such as those involving inferencing skills, may therefore become less challenging for these students.

The improvement in the reading habits of the intervention classes and the positive difference between the control and intervention classes could be attributed to the extensive reading that the students had to undertake. Students were reading for pleasure more frequently than they had before the intervention. This is a further indication of the efficacy of the teaching approach used in the study. Extensive reading helps to develop and improve students' reading ability - a fact that has been reiterated by several researchers (e.g. Day, 2010; Grabe, 2008; Horst, 2005; Nishono, 2007; Pulido, 2009; Stanovich, 2000). Thus, developing students' 
reading habits to improve their reading ability is an important endeavour in reading instruction.

In as much as students improved their affective levels, with substantial effect sizes, and assumed to have achieved the necessary reading development that relates to their affective levels, the intervention, using an affective approach, could be said to have been beneficial and effective. Students' affective reading levels improved, which could indicate that their reading proficiency also improved. A follow-up interview with selected students provided qualitative data on how students had improved their affective levels, strategy use, and reading habits, as well as how these improvements were carried over to reading in their content subjects (Boakye, 2016).

In addition to using the results of the pre-intervention questionnaires to ascertain the comparability of the control and intervention classes, the results also shed light on the affective levels of the students as a group. From the results given in Table 1, students' affective levels were low initially, except for their attitudes towards reading and their interest in reading (high risk group). Although pre-intervention affective levels were low in both groups, the mean figures show that the affective levels of the low risk group were better than those of the high risk group. These results corroborate a previous study by Boakye and Southey (2008) using a similar cohort of students, which showed that the high risk group had relatively lower affective levels for reading than the low risk group.

It is also interesting to note that, although the high risk group had lower affective levels than the low risk group, the former improved most as shown by the results of effect size analysis, which were mainly medium and large. The high risk group needed such an intervention more, and also benefitted more. Both groups, however, needed to improve their affective reading levels, and this indeed seemed to have been brought about by the intervention.

It was expected that there would be a measure of improvement in all classes, as the control classes were also receiving instruction in reading and in academic literacy. Also, as students had been through a term/semester of instruction in other subjects, general academic improvement was expected to have occurred, which could enhance their affective levels. However, in relation to the question of whether there were differences in the level and amount of improvement between the control and intervention classes, the results showed improvement. As to whether the intervention classes improved more than the control classes, and whether the improvements were statistically significant, Tables 5 and 6 show statistically significant improvements for the intervention classes in five of the seven categories. Where the improvements were not statistically significant, mean scores show that the intervention classes improved, whereas in some instances the control classes decreased into negative figures. This shows that the affective levels of first-year students could drop after the start of academic work. Affective support is needed to stabilise and develop students' affect towards reading, especially their self-efficacy, which has been proven to correlate highly with reading proficiency and academic success (Ehrlich, Kurtz-Costes \& Loridant, 1993; Mills et al., 2007:436; Pretorius, 2007). The medium and large effect sizes that were obtained also show the extent to which the intervention was effective in improving students' reading habits, strategy use, and affective levels towards reading. Given the results of this study at tertiary level and numerous studies by Guthrie and his colleagues at school level, the importance of improving students' affective reading levels concurrently with their cognitive reading proficiency cannot be overemphasised. 


\section{CONCLUSION}

The paper presented a quantitative analysis to determine the efficacy of the affective approach to a reading intervention. The standard Academic Reading and Academic Literacy curricula, for the low risk and high risk groups respectively, were enriched with affective techniques to improve students' affective reading levels. The results of paired and independent t-tests showed statistically significant improvement in affective levels, reading habits, and strategy use for the intervention classes in both high risk and low risk groups. Effect size procedures emphasised these improvements by yielding mainly medium or large effects. Thus, the intervention was shown to be not only effective but also highly effective according to the effect sizes. The results also showed that the high risk group had larger effect sizes in respect of improvement. Therefore, for large improvements to be achieved, an integrated approach to reading development is necessary. It would have been beneficial to compare the results of the questionnaire to the students' performance in a standardised reading test. Future research should include standardised pre- and post-intervention tests for comparison with questionnaire results.

\section{REFERENCES}

ALDERSON, JC. 2000. Assessing reading. Cambridge: Cambridge University Press.

ALVERMANN, DE, SF PHELPS \& VG RIDGEWAY. 2007. Content reading and literacy: Succeeding in today's diverse classrooms. New York, NY: Pearson Education.

ANDERSON, N. 1999. Exploring second language reading: Issues and strategies. Boston, MA: Heinle \& Heinle.

BOAKYE, NY. 2016. The efficacy of socio-affective teaching strategies in a reading intervention: Students' views and opinions. Language Matters, 47:(3)393-414. DOI: https://doi.org/10.1080/10228195.2016.1226379

BOAKYE, NY \& L SOUTHEY. 2008. Investigating students' motivations and attitudes towards reading. Journal for Language Teaching, 42(2):1-22.

BOAKYE, NY, J SOMMERVILLE \& L DEBUSHO. 2014. The relationship between socio-affective factors and reading ability: Implications for tertiary reading instruction. Journal for Language Teaching, 48(1):173-213.

DAY, RR. 2010. The benefits of extensive reading (ER). Available from: http://www.oupe.es/es/ELT/supplementarymaterial/Readers/bookworms/Recursos\%20Destacados/the $\% 20$ benefits $\% 20$ of $\% 20$ exte nsive\%20reading.pdf [Accessed: 7 June 2017].

DECI, EL. 1992. The relation of interest to the motivation of behaviour: A self-determination Theory perspective. In Renninger, A, S Hidi, \& A Krapp (Eds), The role of interest in learning and development. Hillsdale, NJ: Lawrence Erlbaum. 43-70.

DECI, EL \& RM RYAN. 2000. Self-determination theory and the facilitation of intrinsic motivation, social development and well-being. American Psychologist, 55:68-78.

DÖRNYEI, Z. 1994. Motivation and motivating in the foreign language classroom. Modern Language Journal, 78(3):273-284.

DÖRNYEI, Z. 2001. Motivational strategies in the language classroom. Cambridge: Cambridge University Press.

DREYER, C \& C NEL. 2003. Teaching reading strategies and reading comprehension within a technology-enhanced learning environment. System, 31(3):349-365. 
EHRLICH, MF, B KURTZ-COSTES \& C LORIDANT. 1993. Cognitive and motivational determinants of reading comprehension in good and poor readers. Journal of Reading Behaviour, 25:365-381.

FAN, Y-C. 2010. The effect of comprehension strategy instruction on EFL learners' reading comprehension. Asian Social Science, 6(8):19-29.

GHONSOOLY, B \& M ELAHI. 2010. Learners' self-efficacy in reading and its relation to foreign language anxiety and reading achievement. Journal of English Language Teaching and Learning, 53(217):45-67.

GLASS, GV, B MCGAW \& ML SMITH. 1981. Meta-analysis. New York, NY: Academic Press.

GRABE, W 2008. Reading in a second language: Moving from theory to practice. Cambridge: Cambridge University Press.

GRABE, W \& FL STOLLER. 2011. Teaching and researching reading. London: Routledge.

GUTHRIE, JT. 2008. Reading motivation and engagement in middle and high school: Appraisal and intervention. In Guthrie, JT (Ed.), Engaging adolescents in reading. London: Corwin Press. 1-16.

GUTHRIE, JT \& A WIGFIELD. 2000. Engagement and motivation in reading. In Karmil, PB \& PD Mosenthal (Eds), The handbook of reading research. Mahwah, NJ: Lawrence Erlbaum. 403-420.

GUTHRIE, JT \& KT Knowles. 2001. Promoting reading motivation. In Verhoeven, L \& CE Snow (Eds), Literacy and motivation: Reading engagement in individuals and groups. Mahwah, NJ: Lawrence Erlbaum Associates. 159-176.

GUTHRIE, JT, A WIGFIELD, P BARBOSA, KC PERENCEVICH, A TABOADA, MH DAVIS, NT SCAFIDDI \& S TONKS. 2004. Increasing reading comprehension and engagement through concept-oriented reading instruction. Journal of Educational Psychology, 96(3):403-423.

GUTHRIE JT \& A WIGFIELD (Eds). 1997. Reading engagement: Motivating readers through integrated instruction. Newark, DE: International Reading Association.

GUTHRIE, JT \& SL KLAUDA. 2014. Effects of classroom practices on reading comprehension, engagement, and motivations for adolescents. Reading Research Quarterly, 49:387-416.

GUTHRIE, JT, WD SCHAFER \& CW HUANG. 2001. Benefits of opportunity to read and balanced instruction on the NAEP. Journal of Educational Research, 94:145-162.

HIDI, S \& V ANDERSON. 1992. Situational interest and its impact on reading and expository writing. In Renninger, A, S Hidi \& A Krapp (Eds), The role of interest in learning and development. Hillsdale, NJ: Lawrence Erlbaum. 215-237.

HORST, M. 2005. Learning L2 vocabulary through extensive reading: A measurement study. The Canadian Modern Language Review, 61:335-382.

KODA, K. 2004. Insights into second language reading: A cross-linguistic approach. Cambridge: Cambridge University Press.

LAU, KL. 2009. Grade differences in reading motivation among Hong Kong primary and secondary students. Journal of Educational Psychology, 79(4):713-33.

MATTHEWSON, GC. 2004. Model of attitude influence upon reading and learning to read. In Ruddell, RB \& NJ Unrau (Eds), Theoretical models and processes of reading. Newark, DE: International Reading Association. 1431-1459.

MCKENNA, MC. 2001. Development of reading attitudes. In Verhoeven, L \& CE Snow (Eds), Literacy and motivation: Reading engagement in individuals and groups. Mahwah, NJ: Lawrence Erlbaum. 135-158. 
MILLS, NA, F PAJARES \& C HERRON. 2007. Self-efficacy of college intermediate French students: Relation to achievement and motivation. Language Learning, 57(3):417-442.

MULLIS, IVS, MO MARTIN, P FOY \& KT DRUCKER. 2012. PIRLS 2011 international results in reading. Chestnut Hill, MA: TIMSS \& PIRLS International Study Center, Boston College. Available from: http://timssandpirls.bc.edu/pirls2011/internationalresults-pirls.html [Accessed: 7 June 2017].

NGWENYA, T. 2010. Correlating first-year law students' profile with the language demands of their content subjects. Per Linguam, 26:74-99.

NEL, C, C DREYER \& M KOPPER. 2004. An analysis of the reading profiles of first-year students at Potchefstroom University: A cross-sectional study and a case study. South African Journal of Education, 24:95-103.

NISHONO, T. 2007. Beginning to read extensively: A case study with Mako and Fumi. Reading in a Foreign Language, 5:271-275.

PAJARES, F. 2006. Self-efficacy during childhood and adolescence: Implications for teachers and partners. In Pajares, F \& T Urden (Eds), Self-efficacious beliefs of adolescents. Greenwich, CT: Information Age. 339-467.

PRESSLEY, M. 2006. Reading instruction that works: The case for balanced teaching. New York, NY: Guilford.

PRETORIUS, EJ. 2000. Inference generation in the reading of expository texts by university students. Unpublished doctoral thesis, University of South Africa, Pretoria.

PRETORIUS, EJ. 2007. Looking into the seeds of time: Developing academic literacy in high poverty schools. Ensovoort, 11(2):105-125.

PULIDO, D. 2009. Developing reading skills in a foreign/second language. In A Cirocki (Ed.), Extensive reading in English language teaching. Munich: Lincom. 27-45.

SCHIEFELE, U. 2009. Topic interest and levels of text comprehension. Available: http://opus.kobv.de/ubp/volltexte/2009/3369/

SQUIRES, S. 2014. The effects of reading interest, reading purpose, and reading maturity on reading comprehension of high school students. Unpublished $\mathrm{PhD}$ thesis, Baker University, USA.

STANOVICH, KE. 2000. Progress in understanding reading: Scientific foundations and new frontiers. New York, NY: Guilford Press.

SWALANDER, L \& K TAUBE. 2007. Influences of family-based prerequisites, reading attitudes and self-regulation on reading ability. Contemporary Educational Psychology, 32(2):206-230. DOI: https://doi.org/10.1016/j.cedpsych.2006.01.002

THAMES, DG \& C REEVES-KAZELSKIS. 1992. Effects of individualized, integrated language arts instruction on the attitudes of poor readers. Paper presented at the Annual Meeting of the Mid-South Educational Research Association, Knoxville, TN, 10-13 November. Available from: http://files.eric.ed.gov/fulltext/ED353570.pdf [Accessed: 7 June 2017].

TAYLOR, S \& D YU. 2009. Socio-economic status and educational achievement: Does education provide a stepping stone out of poverty in South Africa? Transformation Audit, 2009:66-75.

TORGESON, JK. 2002. The prevention of reading difficulties. Journal of School Psychology, 40(1):7-26.

TSE, SK \& X XIAO. 2014. Differential influences of affective factors and contextual factors on high-proficiency readers and low-proficiency readers: A multilevel analysis of PIRLS data from Hong Kong. Assessments in Education, 2(6). Available from: http://www.largescaleassessmentsineducation.com/content/2/1/6 [Accessed: 7 June 2017]. 
VAN KRAAYENOORD, CE \& WE SCHNEIDER. 1999. Reading achievement, metacognition, self-concept and interest: A study of German students in Grades 3 and 4. European Journal of Psychology of Education, 14(3):305-324.

WANG, JH \& JT GUTHRIE. 2004. Modelling the effects of intrinsic motivation, extrinsic motivation, amount of reading, and past reading achievement on text comprehension between US and Chinese students. International Reading Association, 39(2):162-186.

WIGFIELD, A. 1997. Children's motivation for reading and reading engagement. In Guthrie, JT \& A Wigfield (Eds), Reading engagement: Motivating readers through integrated instruction. Newark, DE: International Reading Association.

WIGFIELD, A, JT GUTHRIE, KC PERENCEVICH, A TABOADA, S LUTZ KLAUDA, A MCRAE \& P BARBOSA. 2008. Role of reading engagement in mediating effects of reading comprehension instruction on reading outcomes. Psychology in the Schools, 45(5):432-446.

YAMASHITA, J. 2004. Reading attitudes in L1 and L2, and their influence on L2 extensive reading. Reading in a Foreign Language, 16(1). Available from: http://nflrc.hawaii.edu/rfl/April2004/yamashita/yamashita.html [Accessed: 7 June 2017].

\section{AKNOWLEDGEMENT}

I am grateful to Jaqui Sommervile and Legesse Debusho of the Department of Statistics at the University of Pretoria for assisting me with the statistical analyses.

\section{BIOGRAPHICAL NOTE}

Naomi ANY Boakye is a senior lecturer in the Unit for Academic Literacy at the University of Pretoria. Her research interests include academic reading, sociolinguistics, academic literacy, second language reading, and language and gender. She is currently editor-in-chief of Reading \& Writing. Email: naomi.boakye@up.ac.za 


\section{ADDENDUM}

\section{Questionnaire: Socio-affective factors and strategy use in academic reading}

Dear student

Thank you for your willingness to contribute data on factors affecting reading that will help to improve the Academic Reading module.

Please note that there are no incorrect or false answers since the answers reflect your personal opinion. Your responses will remain anonymous. Even though you are required to supply your student numbers, they will only be used for tallying responses to test performance and not for any other identification purposes. There are no disadvantages for responding to this questionnaire.

For office use

Respondent number

Please tick (using a $\mathrm{X}$ ) the number that best reflects your opinion accurately

\begin{tabular}{|c|c|c|c|c|c|}
\hline Past experiences with reading & 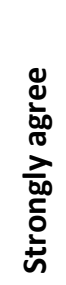 & & 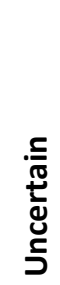 & 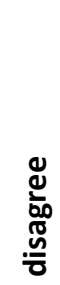 & 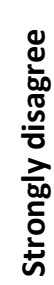 \\
\hline 1.When I was a child I was often taken to the library & 1 & 2 & 3 & 4 & 5 \\
\hline 2. Members of my family used to read to me & 1 & 2 & 3 & 4 & 5 \\
\hline 3. There have always been books in my family's home & 1 & 2 & 3 & 4 & 5 \\
\hline 5. There was a library in my primary school & 1 & 2 & 3 & 4 & 5 \\
\hline 6. There are 20 or more books in my home & 1 & 2 & 3 & 4 & 5 \\
\hline \multicolumn{6}{|l|}{ Reading and social environment } \\
\hline 7. My siblings read a lot & 1 & 2 & 3 & 4 & 5 \\
\hline 8. My parents read a lot & 1 & 2 & 3 & 4 & 5 \\
\hline 9. My friends like reading so they read a lot & 1 & 2 & 3 & 4 & 5 \\
\hline 10. My friends and I discuss books that we read & 1 & 2 & 3 & 4 & 5 \\
\hline 11. I know people who read all kinds of texts & 1 & 2 & 3 & 4 & 5 \\
\hline
\end{tabular}

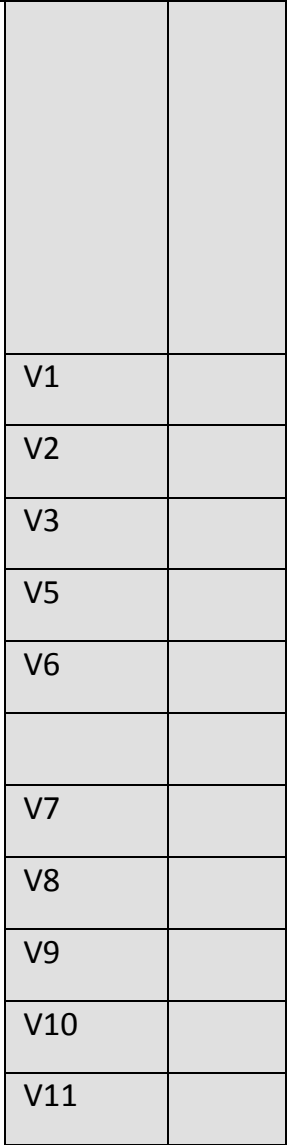




\begin{tabular}{|c|c|c|c|c|c|}
\hline \multicolumn{6}{|l|}{ Interest in reading } \\
\hline 12. I like to read about topics of interest & 1 & 2 & 3 & 4 & 5 \\
\hline 13. I like to read about new things & 1 & 2 & 3 & 4 & 5 \\
\hline 14. I read for pleasure & 1 & 2 & 3 & 4 & 5 \\
\hline 15. I find reading an interesting activity & 1 & 2 & 3 & 4 & 5 \\
\hline 16. If I had more time I would read more & 1 & 2 & 3 & 4 & 5 \\
\hline \multicolumn{6}{|l|}{ Attitude towards reading } \\
\hline $\begin{array}{l}\text { 17. I have always believed that reading was a good } \\
\text { thing to do }\end{array}$ & 1 & 2 & 3 & 4 & 5 \\
\hline 18. I have favourite subjects that I read about & 1 & 2 & 3 & 4 & 5 \\
\hline 19. 1 enjoy reading & 1 & 2 & 3 & 4 & 5 \\
\hline $\begin{array}{l}20 . \text { I find it easy to settle down and concentrate on my } \\
\text { reading tasks }\end{array}$ & 1 & 2 & 3 & 4 & 5 \\
\hline 21. Reading well will help me with my studies & 1 & 2 & 3 & 4 & 5 \\
\hline 22. I can learn a lot from reading & 1 & 2 & 3 & 4 & 5 \\
\hline \multicolumn{6}{|l|}{ Perceptions about own abilities/self-efficacy } \\
\hline 23. I think I read well and with understanding & 1 & 2 & 3 & 4 & 5 \\
\hline 24. I read slowly so I have problems with understanding & 1 & 2 & 3 & 4 & 5 \\
\hline $\begin{array}{l}\text { 25. I have difficulty in completing the reading } \\
\text { assignments given to me }\end{array}$ & 1 & 2 & 3 & 4 & 5 \\
\hline 26. I read slowly so it makes me tired and bored & 1 & 2 & 3 & 4 & 5 \\
\hline $\begin{array}{l}\text { 27. I have difficulty in understanding words ( } 50 \% \text { or } \\
\text { more) in my reading assignments }\end{array}$ & 1 & 2 & 3 & 4 & 5 \\
\hline $\begin{array}{l}\text { 28. I have to translate what I read into my home } \\
\text { language before I really understand }\end{array}$ & 1 & 2 & 3 & 4 & 5 \\
\hline $\begin{array}{l}\text { 29. I have difficulty in understanding idiomatic } \\
\text { language }\end{array}$ & 1 & 2 & 3 & 4 & 5 \\
\hline $\begin{array}{l}\text { 30. I have difficulty in understanding the texts I have to } \\
\text { read at university }\end{array}$ & 1 & 2 & 3 & 4 & 5 \\
\hline $\begin{array}{l}\text { 31. I have difficulty in extracting the main points in what } \\
\text { I read. }\end{array}$ & 1 & 2 & 3 & 4 & 5 \\
\hline $\begin{array}{l}\text { 32. I find it difficult to summarise a text in my own } \\
\text { words }\end{array}$ & 1 & 2 & 3 & 4 & 5 \\
\hline \multicolumn{6}{|l|}{ Reading strategies } \\
\hline $\begin{array}{l}\text { 33. When I read a novel, I read it in a different way from } \\
\text { when I read a textbook }\end{array}$ & 1 & 2 & 3 & 4 & 5 \\
\hline 34. Before I read a book, I look at its contents page and & 1 & 2 & 3 & 4 & 5 \\
\hline
\end{tabular}

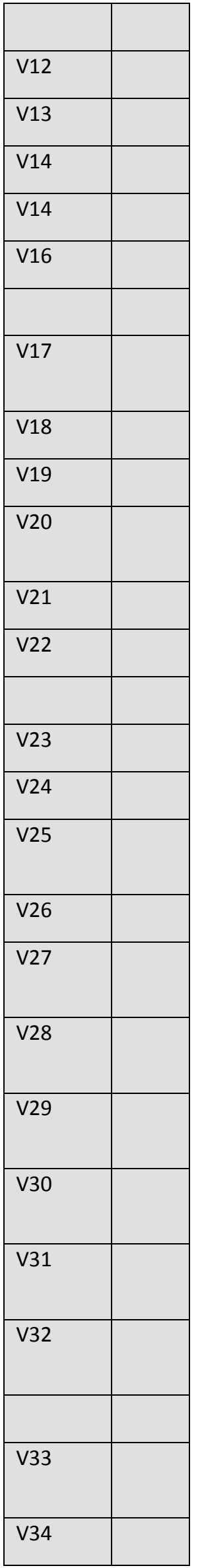




\begin{tabular}{|c|c|c|c|c|c|}
\hline skim through it looking at headings and illustrations & & & & & \\
\hline $\begin{array}{l}\text { 35. The first thing I do when I come across an unknown } \\
\text { word is to look it up in the dictionary }\end{array}$ & 1 & 2 & 3 & 4 & 5 \\
\hline $\begin{array}{l}\text { 36. I record new words and try to memorise them with } \\
\text { their meanings }\end{array}$ & 1 & 2 & 3 & 4 & 5 \\
\hline $\begin{array}{l}\text { 37. I ignore diagrams, maps, graphs, charts, which I } \\
\text { come across in the course of my reading }\end{array}$ & 1 & 2 & 3 & 4 & 5 \\
\hline $\begin{array}{l}\text { 38. I try to relate what I read with my own ideas and } \\
\text { previous knowledge }\end{array}$ & 1 & 2 & 3 & 4 & 5 \\
\hline $\begin{array}{l}\text { 39. I use questions like why, what and how to help me } \\
\text { understand my reading better }\end{array}$ & 1 & 2 & 3 & 4 & 5 \\
\hline 40. I form visual images when I read. & 1 & 2 & 3 & 4 & 5 \\
\hline \multicolumn{6}{|l|}{ Int. motivation-curiosity, involvement, challenge } \\
\hline $\begin{array}{l}\text { 41. I read to learn new information about topics that } \\
\text { interest me }\end{array}$ & 1 & 2 & 3 & 4 & 5 \\
\hline $\begin{array}{l}\text { 42. If I am reading about an interesting topic, I } \\
\text { sometimes lose track of time }\end{array}$ & 1 & 2 & 3 & 4 & 5 \\
\hline 43. I enjoy reading books on various topics & 1 & 2 & 3 & 4 & 5 \\
\hline $\begin{array}{l}\text { 44. If my teacher/lecturer discusses something } \\
\text { interesting, I might read more about it }\end{array}$ & 1 & 2 & 3 & 4 & 5 \\
\hline 45. I feel I connect with characters in good books & 1 & 2 & 3 & 4 & 5 \\
\hline 46. I enjoy reading fictional stories & 1 & 2 & 3 & 4 & 5 \\
\hline 47. I enjoy a long involved story & 1 & 2 & 3 & 4 & 5 \\
\hline 48. I read a lot of adventure and mystery books & 1 & 2 & 3 & 4 & 5 \\
\hline 49. I like hard challenging books & 1 & 2 & 3 & 4 & 5 \\
\hline 50. Reading helps me understand difficult concepts & 1 & 2 & 3 & 4 & 5 \\
\hline $\begin{array}{l}\text { 51. If the assignment project is interesting, I can read } \\
\text { difficult material }\end{array}$ & 1 & 2 & 3 & 4 & 5 \\
\hline $\begin{array}{l}\text { 52. If the book is interesting, I don't care how hard it is } \\
\text { to read }\end{array}$ & 1 & 2 & 3 & 4 & 5 \\
\hline 53. I like to read books that make me think & 1 & 2 & 3 & 4 & 5 \\
\hline \multicolumn{6}{|l|}{ Extrinsic motivation- recognition, competition } \\
\hline 54. I like to get compliments for my reading & 1 & 2 & 3 & 4 & 5 \\
\hline $\begin{array}{l}\text { 55. It is important for me that my teacher and/or } \\
\text { my parents recognise my reading }\end{array}$ & 1 & 2 & 3 & 4 & 5 \\
\hline $\begin{array}{l}\text { 56. I like being the only one who knows the answer to a } \\
\text { question from a text we have read }\end{array}$ & 1 & 2 & 3 & 4 & 5 \\
\hline 57. It is important for me to be among the good & 1 & 2 & 3 & 4 & \\
\hline
\end{tabular}

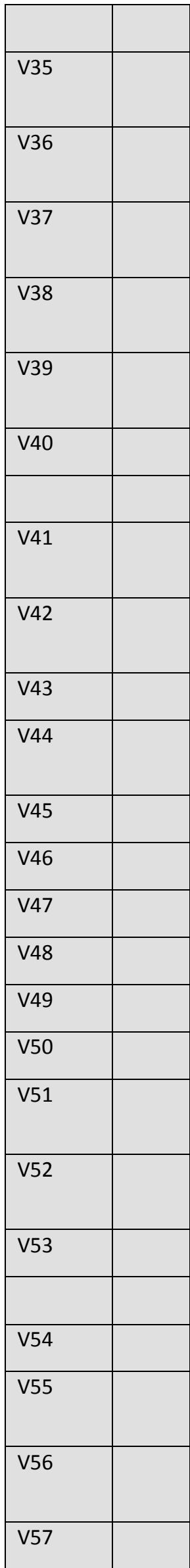




\begin{tabular}{|c|c|c|c|c|c|c|c|c|}
\hline \multicolumn{9}{|l|}{ readers in my class } \\
\hline \multicolumn{4}{|c|}{$\begin{array}{l}\text { 58. I try to get more answers right than my friends' in } \\
\text { reading tasks }\end{array}$} & 1 & 2 & 3 & 4 & 5 \\
\hline \multicolumn{4}{|c|}{$\begin{array}{l}\text { 59. I like to finish my reading and tasks before other } \\
\text { students }\end{array}$} & 1 & 2 & 3 & 4 & 5 \\
\hline \multicolumn{4}{|c|}{$\begin{array}{l}\text { 60. I am willing to work hard in order to read better } \\
\text { than my friends }\end{array}$} & 1 & 2 & 3 & 4 & 5 \\
\hline \multicolumn{9}{|l|}{ Reading habits } \\
\hline \multicolumn{4}{|c|}{ 61. I read one novel each week/month during Holidays } & 1 & 2 & 3 & 4 & 5 \\
\hline \multicolumn{4}{|c|}{$\begin{array}{l}\text { 62. I read one novel each week/month during school } \\
\text { term }\end{array}$} & 1 & 2 & 3 & 4 & 5 \\
\hline \multicolumn{4}{|l|}{ 63. I often read } & & & & & \\
\hline \multicolumn{4}{|l|}{ ii. magazines } & 1 & 2 & 3 & 4 & 5 \\
\hline \multicolumn{4}{|l|}{ iii. novels (fiction) } & 1 & 2 & 3 & 4 & 5 \\
\hline \multicolumn{4}{|l|}{ i. newspapers } & 1 & 2 & 3 & 4 & 5 \\
\hline \multicolumn{4}{|l|}{ iv. academic books } & 1 & 2 & 3 & 4 & 5 \\
\hline \multicolumn{4}{|c|}{ v. any other (e.g. motivational, plays, etc) } & 1 & 2 & 3 & 4 & 5 \\
\hline \multicolumn{4}{|c|}{$\begin{array}{l}\text { 64. I read books/magazines/newspapers in my mother- } \\
\text { tongue }\end{array}$} & 1 & 2 & 3 & 4 & 5 \\
\hline \multicolumn{4}{|c|}{ 65. Newspapers are bought daily/weekly in my home } & 1 & 2 & 3 & 4 & 5 \\
\hline \multicolumn{9}{|l|}{ Personal information } \\
\hline \multicolumn{9}{|l|}{ 66. Faculty } \\
\hline 67. Gender & $\mathrm{F}$ & & $\mathrm{M}$ & & & & & \\
\hline 68. Code for literacy test & 1 & 2 & 3 & & 4 & & & 5 \\
\hline 69. Mother tongue & Eng & Afr & SA A & ican & & רer & & Other \\
\hline Student number & & & & & & & & \\
\hline
\end{tabular}

\begin{tabular}{|l|l|}
\hline V58 & \\
\hline V59 & \\
\hline V60 & \\
\hline V61 & \\
\hline V62 & \\
\hline V63i & \\
\hline V63ii & \\
\hline V63iii & \\
\hline V63iv & \\
\hline V63v & \\
\hline V64 & \\
\hline & \\
\hline
\end{tabular}

\begin{tabular}{|l|l|}
\hline V66 & \\
\hline V67 & \\
\hline V68 & \\
\hline V69 & \\
\hline & \\
\hline
\end{tabular}

